\title{
Globalisation and Economic Growth in South Africa: Do We Benefit from Trade and Financial Liberalisation? ${ }^{1}$
}

\section{Elsabe Loots}

Department of Economics, Rand Afrikaans University

\section{ABSTRACT}

This article investigates whether the process of globalisation, through trade and financial liberalisation, benefits economic growth in emerging market economies in general and in South Africa in particular. The analysis of trade openness and liberalisation in emerging market economies reveals that trade volume has a relative small impact on GDP per capita, while trade liberalisation led to an approximate 50 per cent increase on GDP per capita. The analysis of the financial dimension showed that capital account openness is associated with a 34 per cent increase in real GDP per capita growth over the period, while financial liberalisation seems to have a dramatic impact of approximately 136 per cent. In South Africa approximately 98 per cent of the current growth performance in the country can be explained by the forces of globalisation.

JEL F40, 43

\section{INTRODUCTION}

The process of globalisation has influenced most developing countries. While the opportunities and benefits of the opening of economies are emphasised by proponents and supporters of globalisation, disillusionment is growing among many policy-makers and economists about the costs and risks involved in the globalisation of national economies as well as the impact of it on future growth prospects.

There is a general consensus (see Rodrik, 1997; Frankel, 2000; Hemmer, 2001) that the driving forces behind economic globalisation are a reduction in transport and communication costs in the private sector, reduced policy barriers to trade and investment by the public sector, an increase in the availability of and access to information and technology, and the speed with which information and technology can be transmitted across national boundaries. The most important aspects of economic globalisation therefore include the breaking down of 
national economic boundaries, the liberalisation of international trade, finance and production activities and the growing power of transnational corporations (TNCs) and international financial institutions (Khor, 2000: 3). Economic globalisation therefore manifests itself in various forms such as an increase in international trade, financial flows and foreign direct investment (FDI).

Among the group of developing countries are the emerging market economies ${ }^{2}$, a group of countries that are generally seen as the economic leaders in the developing world. Emerging market economies have since the early 1990s played a more important role in the world economy. During the 1980s and 1990s these economies achieved higher economic growth rates than did developed and developing countries. Emerging market economies averaged real economic growth rates of 4 per cent and 4.1 per cent respectively during the 1980s and 1990s, in comparison with average rates of 3.4 per cent and 3.3 per cent for developing countries and 3.2 per cent and 2.5 per cent on average for the world economy. Emerging economies' exports contribute 23 per cent to world exports and 92 per cent of exports from developing countries. Apart from the fact that emerging markets are highly active on the international trade scene, they are also the recipients of 92 per cent of all FDI inflows to developing countries. Almost all the portfolio flows to developing countries are also directed at emerging economies since their financial markets are more developed than those of the remaining developing countries ${ }^{3}$. These flows are very volatile and subject to emerging market crises, as has been seen in the Mexican peso crisis, the East Asian meltdown, and to a lesser extent the Russian, Turkish and Argentinean defaults.

South Africa re-entered the international economy in the early 1990s at a time when the process of globalisation was beginning to gain momentum. Policy choices were made that led to rapid liberalisation of finance, trade and investment. The question can be raised to what extent did South Africa benefit from this process?

Economic globalisation can be analysed within two distinct dimensions. The trade dimension focuses on the impact of trade openness and liberalisation on economic growth and development. The other dimension is financial or capital account openness and liberalisation. Although literature on a comprehensive measure of globalisation is still lacking, research has been done on the trade and financial dimensions of globalisation, respectively. The aim of this article is firstly to discuss the recent literature on the fields, to establish to what extent globalisation, seen from the perspective of these two dimensions, contributes to economic growth and development in emerging market economies and to test the robustness of the results. The second part of this article will focus on the 
relationship between globalisation and economic growth in South Africa. The article concludes with policy implications and recommendations for the country.

\section{TRADE OPENNESS AND LIBERALISATION IN EMERGING MARKET ECONOMIES}

\subsection{Literature overview}

Traditional economic theory views trade as the engine of growth. Since the early 1980s economists have recommended market-oriented reforms that included as a fundamental component the reduction of trade barriers and the opening of international trade to foreign competition (Edwards, 1993: 1359). The rapidly growing East Asian economies are an excellent example of the economic growth benefits of more open and outward-oriented economies. Multilateral institutions such as the IMF, the World Bank and the OECD also urged developing countries to embark on trade liberalisation and to open their trade as a precondition for receiving financial assistance. Rodrigues and Rodrik (1999: 1) refer to prominent economists such as Krueger and Stiglitz who agree on the positive benefits of outward-oriented trade strategies and external openness for per capita income growth.

A large number of comparative studies on the benefits of liberal trade policies on the growth and economic performance of various countries have been done since the 1970s. Prominent economists such as Bela Balassa, Anne Krueger and Jagdish Bhagwati, to name a few, were involved in these different studies. Edwards (1993: 1365) concluded that the literature on the subject has not always been successful in dealing with precise definitions of trade regimes and trade orientation. To address this issue, the World Bank (1987) constructed an index of trade liberalisation. The index has values of between 1 - in cases of a highly oppressed external sector - and 20 in case of fully liberalised trade. However, most of the cross-country studies during the 1970s and 1980s were plagued by empirical and conceptual shortcomings (Edwards, 1993: 1389). They also focussed mostly on whether inward or outward trade policies are beneficial for economic growth and development, which were naturally the issues of the time. During the late 1980s the emergence of the theory of endogenous economic growth by Romer and Lucas (see Barro, 1998: 5) provided new evidence on the long-run equilibrium relationship between openness and economic growth, although empirical evidence was still lacking.

During the 1990s a new generation of research developed that focussed on whether countries with lower trade barriers grow faster, once other relevant country growth variables are controlled for. Two opposing schools of thought 
developed - the trade liberalisation optimists and the trade liberalisation sceptics. The optimists (see Edwards, 1998:383) include Romer (1992), Grossman and Helpman (1991) and Barro and Sala-i-Martin (1995), who argued that countries that are more open have a greater ability to absorb technological advances generated in developed countries. The sceptics (see Edwards, 1998:383) include Krugmann (1994), Rodrik (1995) and Rodriguez and Rodrik (1999), who argued that the effect of openness of trade on growth is doubtful.

The most widely cited study of the 1990s is the paper by Dollar (1992). He constructed two separate indices, namely an index of real exchange rate distortion and an index of real exchange rate variability. These indices are meant to capture two dimensions of outward orientation and each is negatively correlated with growth over the 1976-1985 period in a sample of 95 developing countries. Rodriques and Rodrik (1999: 15), who tested the results, concluded that the variability index is robust, but that the distortion coefficient is not statistically significant.

This study was followed by the construction of a composite openness index by Sachs and Warner (1995), known as the Sachs-Warner openness indicator. This indicator is a zero-one dummy. The value of zero indicated a closed economy according to any one of the following criteria: If the average tariff rate exceeds 40 per cent, if non-tariff barriers covered more than 40 per cent of imports, if the country has a socialist economy or a state monopoly on exports, and lastly, if the black market premium exceeded 20 per cent during the 1970s and 1980s. If the Sachs-Warner dummy is used, the coefficients seem to be robust in growth regressions. However, when the individual components were tested, it emerged that the dummy's strength mainly derives from the combination of the black market premium and the state monopoly of exports. Both of these variables are less direct measures of trade policy such as tariffs and non-tariff barriers. Rodriques and Rodrik (1999: 24) concluded that "the Sachs-Warner measure is so correlated with plausible groupings of alternative explanatory variables ..... that it is risky to draw strong inferences about the effect of openness on growth based on its coefficient in a growth regression."

Sebastian Edwards (1998) went on to analyse the robustness of the opennessgrowth relationship by using the following already existing nine indicators of openness: The Sachs-Warner openness index, the World Bank integration index, the Edward Leamer openness index (based on the basis of the average residuals from regression of trade flows), the average black market premium, the average import tariff as developed by Barro and Lee (1994), the average coverage of non-tariff barriers (also Barro \& Lee), the Heritage Foundation index of distortions in international trade, the ratio of total revenues on trade taxes to total trade, and lastly, the regression index of Holger Wolf on import distortions. 
Edwards (1998: 386) concluded that "in spite of significant efforts and ingenuity, there has not been too much progress in this area." The vast majority of indices continue to be subject to limitations.

The most recent published study in this field is by Romain Wacziarg (2001). He investigated the links between trade policy and economic growth by using a sample of 57 countries for the years 1970 and 1989. He developed a new measure of trade policy openness based on the policy components of trade shares, using a simultaneous equation system to identify the effect of trade policy on several determinants of growth. The indicators used include the average import rate, the non-tariff barrier coverage rate and the Sachs-Warner index. The results suggested a positive impact of openness on economic growth. Wacziarg (2001: 422) also concluded that trade openness affects growth mainly by raising the ratio of domestic investment to GDP. The criticism from Rodriques and Rodrik (1999: 38) on an earlier version of this analysis focussed on the deficiencies of the Sachs-Warner index. They also question whether the results will hold up when averages of over a decade are used instead of the fiveyear averages that were used in the model.

\subsection{The trade openness and liberalisation effect in a classic growth regression}

From the early 1990s the emerging market economies became more prominent players in the world economy. At that stage fast-growing countries like Singapore, Korea and Malaysia had already expanded their export base. Neighbouring countries in Asia like Indonesia, the Philippines, Thailand and China started to benefit from the spill over benefits of the region. During the late 1980s countries in Latin America changed their inward trade strategies to become more outward-oriented and had settled most of their debt problems of the 1980s. Countries in Eastern Europe entered the world economy in the early 1990s after the abolition of socialist rule. South Africa was also able to extend the range of its trade ties after the abolition of apartheid in 1990.

Since the process of globalisation for emerging market economies started to gain momentum in the early 1990s (see Loots, 2002 for a detailed analysis), it is imperative to analyse this process for the period 1990 to 2000. Although most of the emerging market economies have been included in some of the earlier studies, they have not been analysed as a group as such and during the period covering the 1990s. This study will use a cross-sectional data set for 22 emerging market economies for the period 1990 to 2000. The countries included in the data set are Argentina, Brazil, Chile, China, Colombia, Czech Republic, Egypt, Hungary, India, Indonesia, Israel, Republic of Korea, Malaysia, Mexico, Peru, Philippines, Poland, Singapore, South Africa, Thailand, Turkey and 
Venezuela. Due to data limitations, the Russian Federation and Hong Kong have been excluded from this analysis.

The classic growth regression equation to be used in the analysis is as follows:

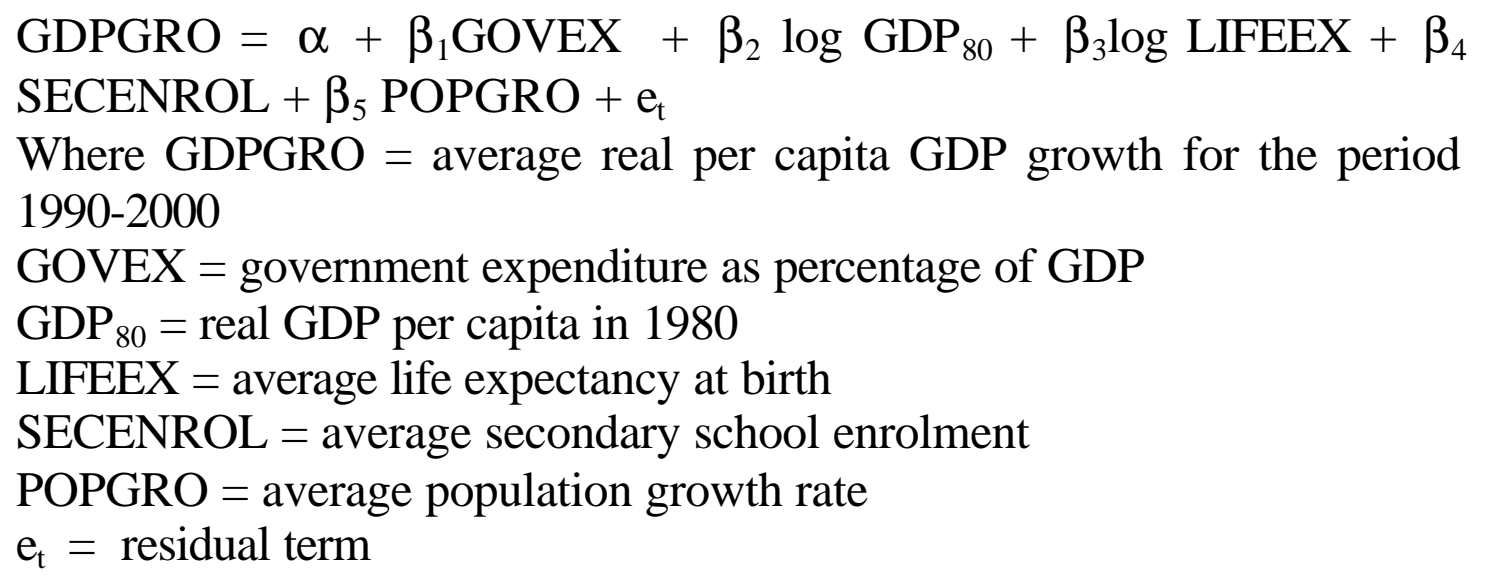

The regression results are reported in Table 1 . The results are broadly consistent with the current growth literature. The 1980 GDP per capita - representative of the initial GDP level - has a significant negative coefficient, indicating that low initial GDP levels imply higher growth rates, conditional upon the other variables included. This is known as the conditional convergence result (Gylfason, 1999: 76; Bekaert et al., 2001: 12). Life expectancy has a positive coefficient indicating that long life expectancy is associated with higher economic growth. The secondary school enrolment variable is also positive and significant suggesting that countries with high levels of human development will achieve higher economic growth. The significantly negative coefficient of government expenditure indicates that countries with large government sectors have lower economic growth rates. In this regression the coefficient of population growth is positive, but insignificant at a 95 per cent confidence level. A possible explanation for this may be that the population growth rate in this group of countries is below the world average and does not therefore serve as a deterrent to growth.

Table I Classic growth regression results

\begin{tabular}{|c|c|c||}
\hline Variable & Coefficient & T-statistic \\
\hline $\mathrm{C}$ & -35.0880 & -1.7691 \\
\hline GOVEX $^{\prime}$ & -0.1129 & -3.5165 \\
\hline $\operatorname{logGDP}_{80}$ & -1.3643 & -3.8868 \\
\hline SELIFEEX & 12.5246 & 2.6629 \\
\hline POCENROL & 0.4143 & 1.9655 \\
\hline
\end{tabular}


Notes: Dependent variable is the average real GDP per capita for the period 1990-2000. Data for the independent variables covers the same period. $\mathrm{R}^{2}=0.7168$

The question that can be raised is whether trade policy or trade volume or both affect economic performance. To test the significance of trade volume on growth, the TRADE variable was introduced in the classic growth regression. This caused major changes in the significance of the coefficients. The regression equation was transformed as follows:

GDPGRO $=\alpha+\beta_{1}$ TRADE $+\beta_{2} \log$ GDP $_{80}+\beta_{3} \log$ LIFEEX $+\beta_{4}$ SECENROL $+\mathrm{e}_{\mathrm{t}}$

Where GDPGRO = average real per capita GDP growth

TRADE $=$ Import plus exports as percentage of GDP

$\mathrm{GDP}_{80}=$ real GDP per capita in 1980

LIFEEX = average life expectancy at birth

SECENROL $=$ average secondary school enrolment

The regression results are reported in Table II. The results of the controls are broadly consistent with those reported in the empirical growth literature. Life expectancy and secondary school enrolment both have positive coefficients. The trade volume coefficient is positive and significant suggesting that, once growth variables are controlled for, countries with higher levels of trade will benefit from higher growth rates. The trade volume coefficient of 0.0086 suggests that, on average, it is associated with approximately one per cent increase in real per capita GDP growth over the period. Stronger evidence of conditional convergence occurs when controlled for trade volume.

Table 2 Trade volume and growth

\begin{tabular}{||c|c|c||}
\hline Variable & Coefficient & T-statistic \\
\hline $\mathrm{C}$ & -51.8040 & -2.2481 \\
\hline TRADE $_{\operatorname{logGDP}} 80$ & 0.0086 & 1.5202 \\
\hline $\operatorname{logLIFEEX}_{\text {SECENROL }}$ & -1.5771 & -3.8232 \\
\hline SEC & 15.2341 & 2.6759 \\
\hline
\end{tabular}

Notes: The dependent variable is the average real GDP per capita for the period 1990-2000. Data for the independent variables covers the same period. $\mathrm{R}^{2}=0.5274$ 
The level of trade policy or the extent to which countries have liberalised their trade, is controversial. As has been indicated in the various studies discussed, no conclusive measure exists. Insignificant results are obtained when the average tariff rate (imports plus exports) is included in a regression specification. Even when the import and export tariff rates are entered individually, no significant coefficients are obtained. The black market premium ${ }^{4}$ also proved to be insignificant, either in the form of the black market premium index or as a $0 / 1$ dummy. To address these problems, a new trade liberalisation indicator (TRADELIB) with a $0 / 1$ value was constructed. A country is classified as having a liberalised economy with a one dummy value if the average export tariff rate for the 1990s is less than one per cent, the average import tariff rate is less than 10 per cent and if the average black market premium index is less than 10 per cnt. The introduction of this new liberalisation indicator in the classic growth regression does not significantly change the coefficients of the growth variables - see Table 3. The liberalisation indicator is positive, but not significant at the 95 per cent confidence level. However, it is still significant at the 75 per cent confidence level. This result suggests that countries that embarked on more liberalised trade regimes will benefit from higher growth rates. It can also be inferred that countries with more liberalised trade regimes have performed better than countries that have isolated themselves. The trade liberalisation coefficient of 0.4987 also suggests that trade liberalisation appears to increase growth by approximately 50 per cent on average during the 11-year period. The evidence on conditional convergence, once controlled for trade liberalisation and other growth variables, also indicates that convergence is quite rapid.

Table 3 Trade liberalisation and growth

\begin{tabular}{||c|c|c||}
\hline Variable & Coefficient & T-statistic \\
\hline $\mathrm{C}$ & -40.1881 & -1.8752 \\
\hline $\operatorname{logGDP}_{80}$ & -1.4964 & -3.7090 \\
\hline SECENROL & 0.0425 & 1.9785 \\
\hline TRADELIB & 0.4987 & 0.7008 \\
\hline GOVEX & -0.1022 & -2.8416 \\
\hline logLIFEEX & 13.6589 & 2.7065 \\
\hline POPGRO & 0.6638 & 1.5665 \\
\hline
\end{tabular}

Notes: The dependent variable is the average real GDP per capita for the period 1990-2000. Data for the independent variables covers the same period. $\mathrm{R}^{2}=0.7258$ 


\subsection{Robustness}

The evidence presented above suggests that trade volume appears to increase growth by only 1 per cent, while trade liberalisation will lead to a 50 per cent increase in growth over the 11-year period. How robust are these results?

The robustness exercise will focus on the various regions among the group of emerging market economies, namely the East Asian countries, Latin America, Eastern Europe and the group that includes the remaining countries (India, Egypt, Israel, South Africa and Turkey). When regional dummies for all the respective regions are stepwise included in the regression, the coefficients for the Asian and other group of countries are significantly positive, while the coefficients for the remaining two regions are negative (see Table 4). This evidence suggests that the benefits of growth through large trade volumes are largely driven by the East Asian emerging markets and to a lesser extent by the other mixed group of emerging economies. Latin American and Eastern European economies are currently not benefiting by increases in trade volumes.

\section{Table 4 Trade volume regression results with regional dummies}

\begin{tabular}{||c|c||}
\hline Region & Coefficient \\
\hline LAdum & -0.1735 \\
\hline Asiadum & 1.6044 \\
\hline EUdum & -2.4555 \\
\hline Otherdum & 0.2781 \\
\hline
\end{tabular}

Regarding the impact of the trade liberalisation indicator on growth, the introduction of regional dummies also proves to be controversial. In contrast with the trade volume evidence, the coefficients for the regional dummies for Latin America and the mixed group are positive, while those for the Asian and Eastern European regions are negative - see Table 5. The significantly positive impact of trade liberalisation seems to be largely driven by countries in Latin America and the mixed group of economies - countries that are classified as the more recent liberalisers.

Table 5 Trade liberalisation regression results with regional dummies

\begin{tabular}{||c|c|}
\hline Region & Coefficient \\
\hline LAdum & 0.6274 \\
\hline Asiadum & -0.6712 \\
\hline EUdum & -3.3963 \\
\hline Otherdum & 0.9246 \\
\hline
\end{tabular}




\section{CAPITAL ACCOUNT OPENNESS AND FINANCIAL LIBERALISATION IN EMERGING MARKET ECONOMIES}

\subsection{Literature overview}

In contrast with studies on trade openness and liberalisation that date back to the early 1970s, a comprehensive analysis on the impact of capital account openness and financial liberalisation is still lacking. One reason is that different theoretical perspectives have different implications for the desirability of liberalising capital flows. Another reason is that empirical analysis so far is very limited and has failed to yield conclusive results (Eichengreen, 2001: 341, Edwards, 2001: 1). Although research on the impact of openness on inward FDI indicates that it is positively associated with growth, studies on the effect of financial capital flows are less conclusive. Some academics also argued that the free mobility of capital during the 1990s - promulgated by the globalisation optimists - was behind the succession of crises that emerging markets experienced during the decade (Edwards, 2001: 1). The crucial question is if domestic financial markets can be counted on to deliver an efficient allocation of resources, why can't international financial markets?

Various studies on financial liberalisation and/or capital account openness, all with differences in emphasis, have been done over the past number of years. Some of these studies will be discussed before an attempt will be made to quantify the phenomenon for the 22 emerging market economies.

A leading study on capital account liberalisation, published in the political science field by Quinn (1997), is widely used by economists. He constructed the Quinn index on current and capital account restrictions for 66 countries for 1973 and 1988. The index on capital account restrictions has values between one and four, with increments of 0.5. A higher value of this index denotes a higher degree of capital mobility. For the period 1960-1989 he reports a positive correlation between the change in his capital account openness indicator and growth. Since capital flows during Quinn's period of analysis mostly took place in developed economies, the positive correlation can be ascribed to capital mobility in these countries.

The most widely-cited study on the correlation between capital account liberalisation and growth is by Rodrik (1998, see Arteta et al., 2001: 4). He did a cross-country study on approximately 100 countries for the period 1975-1989. The binary indicator constructed by the IMF's Exchange Arrangements and Exchange Restrictions was used. A 0/1 dummy was generated for each country. If a country has no capital controls, the dummy has a value of one. Controlling for various growth determinants, he found no statistically significant association 
between capital account liberalisation and GDP per capita growth and questions whether capital flows enhance economic efficiency.

Kraay and Swank (see Eichengreen, 2001: 345) did independent studies in 1998 by using both actual capital inflows and outflows as percentage of GDP as a measure of freedom of capital movements. Although this measure cannot be seen to be an informative indicator of the capital account regime and does not indicate restrictions on capital flows, it may be useful as an indicator of the level of openness.

Klein and Olivei (1999) did a cross-sectional analysis of approximately 92 developed and developing countries for the period 1986 to 1995. As regards the quantification of capital account liberalisation, the authors mention the fact that no single quantitative measure exists to determine capital account openness, especially when studying a widely heterogeneous set of countries. They used two measures: The first of these was the IMF binary indicator, also used by Rodrik. This variable again proves to be statistically insignificant in the model. Second, they calculated the variable SHARE, which represents the portion of years between 1986 and 1995 in which the country had unrestricted capital mobility. Even if SHARE was replaced by ALL, a dummy variable equal to one if a country had no restrictions on the capital account over the whole period, no difference in results was found. They concluded that countries with open capital accounts enjoyed a significantly greater increase in financial depth than countries with continuing capital account restrictions, and that they also enjoyed greater economic growth. However, this positive relationship is only evident in OECD countries. Klein and Olivei (1999: 22) observed that policy reforms in developing countries should require capital account liberalisation only when adequate institutions and sound macroeconomic policies are already in place. They also warn that this policy prescription requires a better understanding of the manner in which openness alters the performance of an economy.

Sebastian Edwards (2001) investigated the effects of capital mobility on economic growth during the period 1981 to 1990 in 61 countries. He used Quinn's index (only available for 1973 and 1988) to measure the degree of capital mobility in different countries. (He also used the IMF-based indicator, but the coefficients become statistically insignificant when included in the model.) His results suggested that, once controlled for other variables, countries that are more integrated into global financial markets have performed better than countries that have isolated themselves. There is also evidence suggesting that an open capital account positively affects growth only after the country has achieved a certain degree of economic development and has achieved a somewhat advanced domestic market, and that this therefore limits the benefits to high-income countries. 
Bakaert, Harvey and Lundblad (2001) did a comprehensive cross-sectional country analysis on whether financial liberalisation spurs growth. The study covers four different data samples. Samples I and II include 95 and 75 countries, respectively, and samples III and IV include 50 and 28 countries, respectively. They also constructed an official financial liberalisation indicator based on official liberalisation dates in countries. This is based on the dates of regulatory changes when foreigners could access the local market, normally when a sharp upward movement in equity capital flows is evident. The official liberalisation indicator takes a value of one when the equity market is liberalised and zero otherwise. They conclude that, once controlled for determinants suggested by the empirical growth literature, liberalisation appears to increase the real per capita GDP growth rate by an average of 1.13 per cent over a five-year period. Differentiating across liberalising countries, a large secondary school enrolment, a small government sector and an Anglo-Saxon legal system tend to enhance the liberalisation effect. They also proved that the conditional convergence effect is larger once financial liberalisation is accounted for.

Arteta, Eichengreen and Wyplosz (2001) did a more cautious analysis on a sample of 61 countries. They re-tested the results obtained by the Edwards analysis by using the Quinn index. They also tested the interaction between capital account openness and the black market premium. While they find indications of a positive association between capital account liberalisation and growth, their evidence indicates that the effects vary with time, with how capital account liberalisation is measured and with how the relationship is estimated. They also find evidence indicating the need to eliminate major macroeconomic imbalances before opening the capital account.

All these studies have difficulties in measuring the "true" degree of capital mobility and/or liberalisation. Most studies measure capital controls by constructing a dummy variable for the presence or absence of controls. Through this measure they are actually ignoring the intensity of controls or whether gradual relaxation of restrictions took place. The studies also differ in results due to aspects like the choice of the liberalisation variable, the number of countries included in the cross-country empirical analysis, the period covered (for instance during the 1980s capital flows to developing countries were nonexistent due to the debt crises) and the extent to which developed, developing and low-income economies are included. What seem to be important conclusions from these studies is the sequencing of reforms. Eichengreen (2001: 353) concluded that countries that first complete the process of macroeconomic stabilisation, allowing them to remove exchange controls and other current account distortions, experience stronger growth effects through capital account openness. 


\subsection{The capital account openness and financial liberalisation effect in a classic growth regression}

Capital account openness and financial liberalisation can generally been seen as two related processes. In the preceding part the difficulty in the quantification of these processes was discussed. For the purpose of this study, various variables were considered. The existence of a black market premium in the market for foreign exchange, either in the index format or as a dummy, was tested, but seems insignificant. The Standard and Poor investor credit ratings for countries, used in the dummy variable format, did not provide a significant fit. Enough evidence exists on the insignificant fit of the IMF-based indicator. The IMF only started to publish data on capital controls in 1996, and the absence of comparable data for earlier years means that its indicator cannot be used here. The Quinn index, which is widely used in analysis done on the period of the 1980s, is only available for the 1970s and 1980s.

For the purpose of this study, the following two measures will be used: First, the inflow and outflow of capital, as percentage of GDP, will be used to measure the free flow of capital or capital account openness. Second, a financial liberalisation dummy for the individual countries will be constructed by using the Bekeart and Harvey (see Bekeart et al., 2001:appendix table A1) official liberalisation dates of countries. Countries that were liberalised before 1992 will have a value of one and those after 1992 a value of zero. Since most developing countries in general experience an outflow of funds immediately after liberalisation, it can be assumed that the benefits of liberalisation for growth are not immediate, as is the case in developed countries. The inclusion of these two variables will be tested in the already specified standard growth regression.

The regression equation representing capital account openness is as follows:

GDPGRO $=\alpha+\beta_{1}$ CAPINF $+\beta_{2} \log$ GDP $_{80}+\beta_{3} \log$ LIFEEX $+\beta_{4}$ SECENROL $+\beta_{5}$ POPGRO $+e_{t}$

Where GDPGRO = average real per capita GDP growth for the period 1990-2000

CAPINF $=$ gross FDI and portfolio investment as percentage of GDP

$\mathrm{GDP}_{80}=$ real GDP per capita in 1980

LIFEEX = average life expectancy at birth

SECENROL $=$ average secondary school enrolment

POPGRO = average population growth rate 


\section{Table 6 Capital account openness and growth}

\begin{tabular}{|c|c|c|}
\hline Variable & $\overline{\text { Coefficient }}$ & T-statistic \\
\hline $\mathrm{C}$ & -50.3974 & -1.9777 \\
\hline CAPINF & 0.2316 & 1.3283 \\
\hline $\log \mathrm{GDP}_{80}$ & -1.8242 & -3.9857 \\
\hline logLIFEEX & 14.8320 & 2.3885 \\
\hline SECENROL & 0.0355 & 1.3398 \\
\hline POPGRO & 0.5006 & 1.0396 \\
\hline
\end{tabular}

Notes: The dependent variable is the average real GDP per capita for the period 1990-2000. Data for the independent variables covers the same period. $\mathrm{R}^{2}=0.5478$

The regression results are summarised in Table 6. The introduction of the capital openness indicator does not significantly change the coefficients, with the exception of the coefficient on government expenditure, which was subsequently omitted from the regression. However, the capital openness indicator is positive and significant with a coefficient of 0.2316. This suggests that capital account openness is associated with a 23.1 per cent increase in real GDP per capita over the 11-year period. Strong evidence on conditional convergence is also present once controlled for capital account openness.

When the financial liberalisation variable is introduced, the regression equation is as follows:

GDPGRO $=\alpha+\beta_{1}$ FINLIB $+\beta_{2} \log$ GDP $_{80}+\beta_{3} \log$ LIFEEX $+\beta_{4}$ SECENROL $+\beta_{5}$ POPGRO $+e_{t}$

Where FINLIB = financial liberalisation variable

The regression results are summarised in Table 7 . The regression results do not change significantly with the introduction of the financial liberalisation variable. The liberalisation indicator is positive and significant with a coefficient of 1.3590. This suggests that countries that liberalised before 1992 experienced an average increase of 135.9 per cent over the 11-year period in their respective GDP per capita growth rates. These results suggest that, once controlled for other growth variables, countries that are more integrated into financial markets have performed better than countries that isolated themselves. This evidence is in line with the conclusions by Edwards (2001: 13). 


\section{Table $7 \quad$ Financial liberalisation and growth}

\begin{tabular}{|c|c|c|}
\hline Variable & Coefficient & T-statistic \\
\hline $\mathrm{C}$ & -77.6544 & -3.2869 \\
\hline FINLIB & 1.3590 & 1.3846 \\
\hline $\operatorname{logGDP}{ }_{80}$ & -1.8835 & -4.0146 \\
\hline logLIFEEX & 21.0961 & 3.6385 \\
\hline SECENROL & 0.0560 & 1.8103 \\
\hline POPGRO & 0.4282 & 0.8832 \\
\hline
\end{tabular}

Notes: The dependent variable is the average real GDP per capita for the period 1990-2000. Data for the independent variables covers the same period. $\mathrm{R}^{2}=0.5517$

\subsection{Robustness}

The evidence cited above suggests that capital account openness appears to increase growth by 23 per cent over the period, while countries that introduced financial liberalisation in the early 1990s experienced an approximate 136 per cent increase in growth over the 11-year period. How robust are these results?

The robustness of these results can be analysed by incorporating regional dummy variables into the respective regression equations. Tables 8 and 9 represent the coefficients of the regional dummy variables for Latin America, East Asia, Eastern Europe and the rest of the countries (India, Egypt, Israel, South Africa and Turkey). For the East Asian economies the capital account openness and financial liberalisation effect is positive and significant. Although the mixed group of countries also have a positive coefficient, it is not highly significant. The statistical and economic impact is the strongest in the East Asian region. The coefficients for the Latin American countries and those for Eastern Europe are significantly negative. The results on capital account openness and financial liberalisation are therefore strongly driven by the emerging East Asian economies. These countries introduced major changes in their respective financial sector policies during the 1980s and early 1990s (see Beim \& Calomiris, 2001: 139-141 for a detailed analysis). These policy reforms include the liberalisation of FDI regimes, the removal of credit controls, interest rate deregulation, the lifting of restrictions on foreign and local banks, the privatisation of state banks and stock exchanges and the relaxation of measures curbing international capital flows. This could explain the large coefficients obtained for capital account openness and especially the excessively high financial liberalisation coefficient. 
Table 8 Capital account openness regression results with regional dummies

\begin{tabular}{||c|c|}
\hline Region & Coefficient \\
\hline LAdum & -0.6983 \\
\hline Asiadum & 1.3831 \\
\hline EUdum & -4.0182 \\
\hline Otherdum & $0.2711^{*}$ \\
\hline
\end{tabular}

* Statistically insignificant

Table 9 Financial liberalisation regression with regional dummies

\begin{tabular}{||c|c|}
\hline Region & Coefficient \\
\hline LAdum & -0.8141 \\
\hline Asiadum & 1.3569 \\
\hline EUdum & -2.9678 \\
\hline Otherdum & $0.1281^{*}$ \\
\hline
\end{tabular}

Statistically insignificant

\section{CONCLUDING REMARKS ON EMERGING MARKET ECONOMIES}

Economic theory creates strong presumptions that trade and financial liberalisation has favourable effects on economic growth. This paper investigates these phenomena by discussing the recent literature on the field, analysing it for the 22 emerging market economies in a classic growth regression and testing the robustness for the different regions. The trade dimension focused on the impact of trade openness and liberalisation on growth. The evidence suggests that trade volume seems to have a relatively small impact on real GDP per capita over the 11-year period. It is also mainly driven by the emerging economies in the East Asian region. The fact that this group of countries has been the drivers of the trade volume process can serve as an explanation on why the impact is relatively small because most of the countries in this region embarked on trade promotion and received the growth benefits in earlier decades. In contrast, countries that embarked on liberal trade regimes over the past decade experienced an approximate 50 per cent increase in growth over the period. The large positive impact seems to be driven mainly by countries in Latin America and the mixed group of economies. Again the relatively large impact during the past decade is due to the relatively recent (late 1980s and early 1990s) trade liberalisation initiatives in Latin American countries. 
The financial dimension focused on capital account openness and financial liberalisation. The evidence on capital account openness suggests that it is associated with a 34 per cent increase in real GDP per capita growth over the period. Financial liberalisation seems to have a dramatic impact of approximately 136 per cent over the 11-year period. The results on both the financial liberalisation variables indicate that it is strongly driven by the emerging East Asian region and can be ascribed to the dramatic turnabout in the financial sector policies during the late 1980s and early 1990s. These countries have experienced significantly large increases in FDI flows since the early 1990s. Regarding financial liberalisation, the change in policy reforms allowed a more active role for private sector involvement on financial markets for the first time.

\section{GLOBALISATION AND THE SOUTH AFRICAN ECONOMY}

From the cross-sectional empirical analysis on trade and financial openness and liberalisation, respectively, it is evident that not all countries/regions benefited to the same extent. It is therefore imperative to establish what the impact of globalisation is on the South African economy.

South Africa extended its trade ties in the international economic arena in the early 1990s when the forces of globalisation became more prominent. A general analysis indicates that the expansion in the South African economy only started to take off in 1994. The trade pattern since 1990 is shown in Figure 1. From the figure it is evident that, after a period of stagnation during the early 1990s, international trade started to increase from the latter part of 1994. Financial flows in the form of FDI, portfolio and other investment flows made a dramatic turn-around from dominantly negative flows to mostly positive inflows from the third quarter in 1994 (see Figure 2). In contrast with the long-term upward trend in trade since 1994, the investment flows are still extremely volatile. The volatility can be explained, firstly, by the fact that South African companies and individuals - due to exchange rate restrictions and international sanctions - did not have the opportunity to invest abroad. Since 1994 a large number of South African companies expanded to become trans-national companies. The gradual relaxation of exchange control also permitted companies and individuals to invest abroad. A second explanation for the volatility in capital flows is the relative openness of the capital market for foreign speculative attacks against the Rand. 


\section{Figure 1 Trade as percentage of GDP}

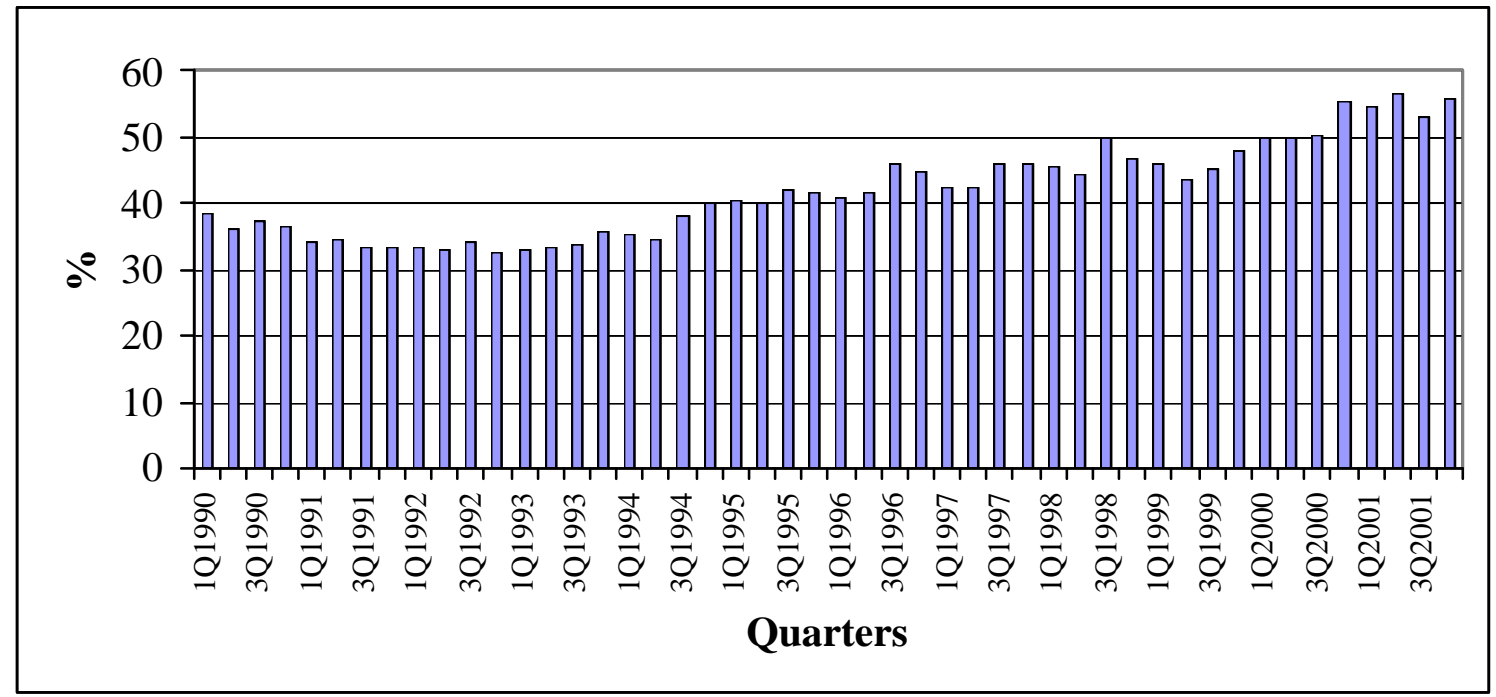

Source: South African Reserve Bank, Quarterly Bulletin

\section{Figure 2 Total investment to GDP}

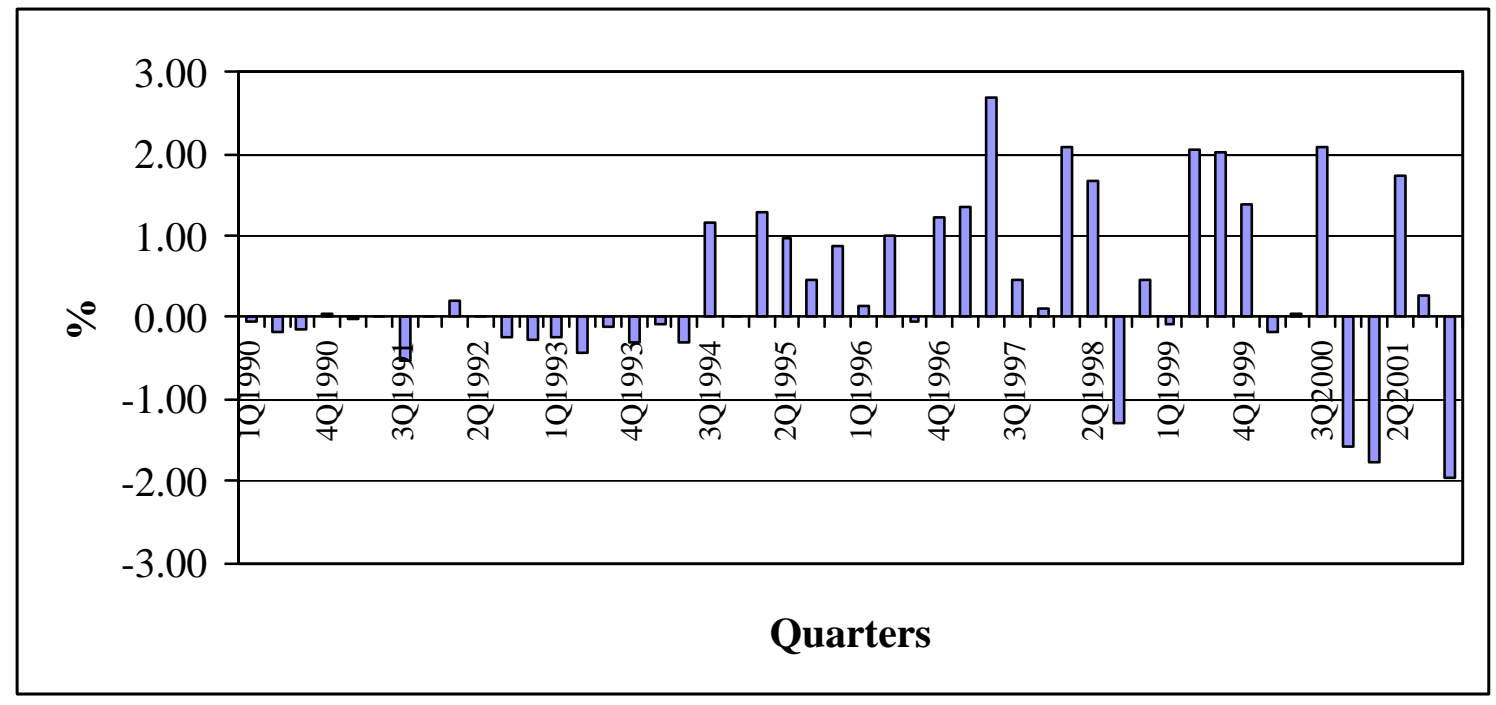

Source: South African Reserve Bank, Quarterly Bulletin

Since economic globalisation includes both the trade and financial dimensions, the simultaneous effect on the South African economy will be tested for the period 1990 to 2001 on a quarterly basis. The proxies for globalisation to be used in the model are as follows:

1. Trade openness will be represented by the total value of imports plus exports, as percentage of GDP. Data from the South African Reserve Bank Quarterly Bulletin will be used.

2. The proxy for trade liberalisation is more contentious. In the case of emerging market economies, the total taxes received by government on 
international trade transactions, as percentage of total imports and exports, respectively, were used. This figure is substantially lower than the average tariff rates being used in the Sachs-Warner openness index, where the average nominal tariff rate is used. For the South African exercise it was decided to use the import weighted average tariff rate, which is a more accurate reflection of the extent or level of trade restrictions. The latter rate also seems to be more in line with the rate suggested in the Sachs-Warner openness index. The other two variables included in the latter index, namely the black market premium on foreign exchange and the socialist economy/state monopoly on exports, are not relevant factors to be taken into account for the South African economy. The data source for the South African data is based on independent research done by the Industrial Development Corporation.

3. Capital account openness will be represented by the total inflow plus outflow of investment (FDI, portfolio investment and other investment), as percentage of GDP. The data source is the South African Reserve Bank Quarterly Bulletin.

4. The proxy for financial liberalisation is slightly more complex. In most international studies a dummy variable is used with 0/1 values. Such dummy variables simply indicate the presence or absence of controls and cannot include the gradual relaxation of exchange and other capital controls, which is the case in the South African economy. To compensate for the gradual relaxation of controls, a financial liberalisation variable is constructed according to the six most prominent dates of exchange control relaxation measures in South Africa. The dates have been chosen based on research by Botha (1999) and the announcements in various Budget Speeches (see National Treasury). The six most prominent announcements for the period 1990-2001 are in March 1995, when the Financial Rand was abolished; July 1995, when local insurance companies, pension funds and unit trusts were allowed for the first time to undertake foreign investment through the so-called asset swap arrangements; March 1997, when the Minister of Finance announced that most controls on current account transactions would be abolished, travel allowances for individuals were increased and corporations could invest more abroad and raise foreign funds; March 1998, when the Minister announced the further relaxation of exchange controls for individuals and corporations; March 2000, when it was announced that companies would be allowed to use local cash holdings to finance new foreign finance and repay foreign debt, corporate asset swaps may be used to finance new foreign investments, unit trusts would be able to invest 20 per cent of total assets through asset swaps, certain currency transfers by pension funds, insurers and unit trusts would be allowed and a further increase in travel allowances; March 2001, when the Minister announced that although the 
asset swap mechanism pertaining to institutions is terminated, South African firms are allowed to increase the limit on their new investments abroad from R50 million to R750 million in Africa and R500 million in the rest of the world. The value of the financial liberalisation variable for the period 1990-1995 would be zero, with increments of 0.5 for each additional capital account relaxation, starting with the March 1995 abolition of the Financial Rand.

The dependent variable to be used in the regressions is the real GDP and not per capita income growth as $\dot{s}$ used in the classical growth regressions. Since the latter is only available on an annual basis and would only provide a very limited time series, it was decided to rather test the impact of globalisation on a quarterly basis since 1990 by using the real GDP at annualised rates.

The regression equation is as follows:

$\log$ GDP $=\alpha+\beta_{1}$ IMEXGDP $+\beta_{2}$ AVIMTAR $+\beta_{3}$ TOTINGDP $+\beta_{4}$ GRADFINLIB $+e_{t}$

Where GDP $=$ real GDP

IMEXGDP = Total value of imports plus exports, as percentage of GDP.

AVIMTAR $=$ Import weighted average tariff rate

TOTINGDP $=$ Total inflow plus outflow of investment, as percentage of GDP

GRADFINLIB $=$ Financial liberalisation variable

The regression results are shown in Table X. All the coefficients prove to be statistically significant. The coefficient for GRADFINLIB is 0.0204 , indicating that the gradual relaxation of capital account controls leads to, ceteris paribus, an approximate 2 per cent increase in real GDP. The IMEXGDP and TOTINGDP coefficients of 0.0053 and 0.0042 , respectively, indicate in each case a positive, but relatively small (less than one per cent) impact on GDP. The coefficient of AVIMTAR is -0.0039 , indicating that a one per cent decrease in the average tariff rate will, ceteris paribus, increase economic growth by approximately 0.3 per cent. The adjusted $R^{2}$ of 0.9798 indicates that approximately 98 per cent of the future change in economic growth can be explained by globalisation, which is a fairly strong fit. 


\section{Table 10 Globalisation regression}

\begin{tabular}{|c|c|c||}
\hline Variable & Coefficient & T-statistic \\
\hline C & 13.0334 & 380.3946 \\
\hline IMEXGDP & 0.0053 & 7.0830 \\
\hline AVIMTAR & -0.0039 & -3.9088 \\
\hline TOTINGDP & 0.0042 & 2.2281 \\
\hline GRADFINLIB & 0.0204 & 3.6193 \\
\hline
\end{tabular}

Notes: The dependent variable is the log of the real GDP. $R^{2}=0.9798$

The standardised beta coefficients of the independent variables can be used to determine the greatest substantive significance or the strongest relationship in the globalisation model (see Table 11). The standardised beta coefficients indicate that trade volume (XEXIM) has the largest impact on growth with a contribution of 48.7 per cent to the change in real GDP. However, this can only be classified as a moderate positive relationship. The second largest contribution is from the financial liberalisation variable (XFINLIB) with a positive but weak value of 27.5 per cent. This is followed by a weak negative relationship between GDP and trade liberalisation (XAVIMTAR). The smallest contribution is from total investment flows (XINV) with a mere 5.5 per cent contribution, indicating that the benefit for the South African economy through capital account openness is negligible. This could be attributed to various factors. A large number of South African companies expanded to become TNCs after 1994 and expanded their activities abroad. The gradual relaxation of capital controls also contributed to individuals and companies investing abroad. The volatility of portfolio flows due to various emerging market crises can naturally not be ignored.

\section{Table 11 Standardised beta coefficients}

\begin{tabular}{||c|c|c||}
\hline Variable & Coefficient & T-statistic \\
\hline XINV & 0.0547 & 2.2350 \\
\hline XAVIMTAR & -0.2462 & -3.9755 \\
\hline XFINLIB & 0.2749 & 3.6568 \\
\hline XEXIM & 0.4868 & 7.1601 \\
\hline
\end{tabular}

It can be concluded that economic globalisation has a definite positive impact on the South African economy. The adjusted $\mathrm{R}^{2}$ indicates that approximately $98 \mathrm{per}$ cent of the change in the real GDP is explained by globalisation. The South African economy is also less sensitive to trade variations than it is to the gradual liberalisation of capital controls. The fact that trade has been liberalised, also has a positive impact on the economy. The strongest impact on the real GDP is 
coming from trade, followed by a weaker, but still significant, influence from the financial and trade liberalisation variables, respectively. Total investment has a negligible but still significant influence in the model, due to the volatility in these flows.

\section{POLICY IMPLICATIONS AND RECOMMENDATIONS}

The globalisation process in emerging market economies, including South Africa, proved to have mixed results - some positive and others negative. In general, what seems to be important is the timing and sequencing of policy changes. From a trade perspective, the benefits of trade volumes in growth seem to be fairly small in the 1990s. The trade liberalisation impact is much larger, especially in the case of Latin American countries, where liberalised trade policies had an immediate impact on growth. The financial liberalisation side is more complex. In this regard the liberalisation of FDI regimes on other restrictive flows and ownership on capital in East Asia had an immediate and excessively strong impact on growth.

The South African economy is more complex. South Africa re-entered the international economy from isolation at a time when the forces of globalisation especially for developing countries - seemed to gain momentum. Although the economic growth pattern is lower than acceptable norms in other emerging economies, the forces of globalisation seems to be stronger than expected. Approximately 98 per cent of the current growth performance in the country can be explained by the forces of globalisation. The regression results also indicate that the South African economy is benefiting from the gradual relaxation of exchange controls. The relative small impact of trade volume on economic growth is in line with the conclusions in international literature in this regard. Sceptics like Krugmann and Rodrik (see Edwards, 1998: 383) state that the effect of trade openness on growth "is, at best, very tenuous, and at worst, doubtful". The volatility in investment flows also has a relatively weak impact on the GDP. The benefits of the decrease in the nominal average import tariff indicate that, on average, import tariffs are at a competitive level. The variables that have the greater substantive significance in the model are the proxy for trade volume, followed by the financial liberalisation variable, the trade liberalisation variable and, lastly, the negligible capital account openness variable.

To conclude, according to the analysis the gradual financial and trade liberalisation did not distort the economy and contributed positively to growth. The trade impact is still moderate and could have a larger impact when exports are increased. The variable that demands greatest attention by policy makers is 
that which relates to total investment flows to the country. Less volatility can be created by sustainable long-term FDI inflows, which will create a more stable environment and curb volatile portfolio flows.

\section{ENDNOTES}

1 Based on a paper presented at the Tips Forum 2002, 9 September 2002, Johannesburg.

2 The Economist's classification of emerging market economies has been used. This group of countries includes Argentina, Brazil, Chile, China, Colombia, Czech Republic, Egypt, Hong Kong, Hungary, India, Indonesia, Israel, Korea (Rep), Malaysia, Mexico, Peru, Philippines, Poland, Russian Federation, Singapore, South Africa, Thailand, Turkey and Venezuela.

3 See Loots, 2002 for a detailed analysis on the globalisation trends in emerging market economies.

4 The black market premium represents the black market premium index, a measure of the extent of rationing in the market for foreign currency and therefore a measure of exchange rate policy. The theoretical reasoning for including the black market premium is that, under certain conditions, foreign exchange restrictions act as a trade barrier.

\section{REFERENCES}

1 ARTETA, C., EICHENGREEN, B. \& WYPLOSZ, C. (2001) "When does capital account liberalisation help more than it hurts?", National Bureau of Economic Research, Working Paper, W8414, August, Cambridge MA.

2 BARRO, R.J. (1998) Determinants of Economic growth. A Cross-County Empirical Study, MIT Press, Cambridge MA.

3 BARRO, R.J. \& LEE, J. (1994) "Sources of economic growth", CarnegieRochester Conference Series on Public Policy, June.

4 BARRO, R.J. \& SALI-I-MARTIN, X. (1995) Economic Growth, McGraw-Hill, New York.

5 BEIM, D.O. \& CALOMIRIS, C.W. (2001) Emerging Financial Markets, McGraw-Hill, Boston.

6 BEKEART, G., CAMPBELL, R.H. \& LUNDBLAD, C. (2001) "Does financial liberalisation spur growth?", National Bureau of Economic Research, Working Paper, W8245, April, Cambridge MA.

7 BOTHA, Z.C. (1999) "The exchange rate system in South Africa - some aspects of past, present and future management policies", Paper presented at the Annual EBM Research Conference, Port Elizabeth, November. 
8 DOLLAR, D. (1992) "Outward-oriented developing economies really do grow more rapidly: Evidence from 95 LDCs, 1976-85", Economic Development and Cultural Change, April.

9 EDWARDS, S. (1993) "Openness, trade liberalization, and growth in developing countries", Journal of Economic Literature, 31, September.

10 EDWARDS, S. (1998) "Openness, productivity and growth: What do we really know?", The Economic Journal, 108, March.

11 EDWARDS, S. (2001) "Capital mobility and economic performance: Are emerging market economies different?", National Bureau of Economic Research, Working Paper, W8076, January, Cambridge MA.

12 EICHENGREEN, B. (2001) "Capital account liberalisation: What do cross-country studies tell us?”, The World Bank Economic Review, 15(3), Oxford University Press.

13 FRANKEL, J.A. (2000) "Globalisation of the economy", National Bureau of Economic Research, Working Paper, W7858, August, Cambridge MA.

14 GROSSMAN, G. \& HELPMAN, E. (1991) Innovation and Growth in the Global Economy, MIT Press, Cambridge MA.

15 GYLFASON, T. (1999) Principles of Economic Growth, Oxford University Press, New York.

16 HEMMER, H.R. (2001) "Developing countries - Victims or beneficiaries of globalisation?", Paper presented at the Konrad Adenauer Foundation Workshop, Johannesburg, 19 June.

17 HOLDEN, M. (2000) 'Openness, the terms of trade and trade policy in natural resource economies", South African Journal of Economics, 68(2), Pretoria.

18 KHOR, M. (2000) "Globalisation and the South: Some critical issues", UNCTAD, Discussion Papers, 147, April.

19 KLEIN, M. \& OLIVEI, G. (1999) "Capital account liberalization, financial depth and economic growth", National Bureau of Economic Research, Working Paper, W7384, October, Cambridge MA.

20 LOOTS, E. (2002) "Globalisation, emerging markets and the South African economy", The South African Journal of Economics, 70(2), March, Pretoria.

21 NATIONAL TREASURY (1997-2001) Budget Speeches, Web page: www.treasury.gov.za

22 QUINN, D (1997) "The correlates of change in international financial regulation", American Political Science Review, 91(3), September.

23 RODRIK, D. (1997) "Trade, social insurance and the limits to globalisation", National Bureau of Economic Research, Working Paper, W5905, January, Cambridge MA.

24 RODRIK, D. (1998) "Who needs capital-account convertibility?", Essays in International Finance, 207, May, Princeton.

25 RODRIQUES, F. \& RODRIK, D. (1999) "Trade policy and economic 
growth", National Bureau of Economic Research, Working Paper, W7081, April, Cambridge MA.

26 SACHS, W. \& WARNER, A. (1995) "Economic reform and the process of global integration", Brookings Papers on Economic Activity, Washington DC.

27 SOUTH AFRICAN RESERVE BANK Quarterly Bulletin, Various Issues, Pretoria.

28 WACZIARG, R. (2001) "Measuring the dynamic gains from trade", The World Bank Economic Review, 15(3), Oxford University Press.

29 WORLD BANK (2002) World Development Indicators, CD Rom, World Bank: Washington DC. 